\title{
Optimization of high-pressure jet assisted turning process by Taguchi method
}

\author{
Sekulic, M. ${ }^{a}$, Kovac, P. ${ }^{a}$, Gostimirovic, M. ${ }^{a}$, Kramar, D. ${ }^{b,}$ \\ ${ }^{a}$ Faculty of Technical Sciences, University of Novi Sad, Trg Dositeja Obradovica 6, 21000 Novi Sad, Serbia \\ ${ }^{b}$ Faculty of Mechanical Engineering, University of Ljubljana, Askerceva 6, 1000 Ljubljana, Slovenia, EU
}

\section{A B S T R A C T}

This paper outlines the Taguchi optimization methodology, which is applied to optimize cutting parameters in high-pressure jet assisted turning when machining Inconel 718. Turning parameters evaluated are the diameter of the nozzle $D_{n}$, the pressure of the jet $P$, the cutting speed $V_{c}$, the feed rate $f$ and the distance between the impact point of the jet and the cutting edge $d$. The experiments were conducted by using $L_{27}\left(3^{13}\right)$ orthogonal array as suggested by Taguchi. Signal-to-Noise (S/N) ratio and Analysis of Variance (ANOVA) are employed to analyze the effect of high-pressure jet assisted turning parameters on the main cutting force and surface roughness, in other words to find optimal levels of the process parameters. The study shows that the Taguchi method is suitable to solve the stated problem with minimum number of trials.
\end{abstract}

\author{
ARTICLE INFO \\ Keywords: \\ High-pressure jet assisted turning \\ Taguchi method \\ Optimization \\ *Corresponding author: \\ davorin.kramar@fs.uni-lj.si \\ (Kramar, D.)
}

\section{References}

[1] Choudhury, I. A., El-Baradie, M. A. (1998). Machinability of nickel-base super alloys: a general review, Journal of Materials Processing Technology, Vol. 77, 278-284.

[2] Courbon, C., Kramar, D., Krajnik, P., Pušavec, F., Rech, J., Kopac, J. (2009). Investigation of machining performance in high-pressure jet assisted turning of Inconel 718: An experimental study, International Journal of Machine Tools\&Manufacture, Vol. 49, 1114-1125.

[3] Bajic, D., Jozic, S., Podrug, S. (2010). Design of experiment's application in the optimization of milling process, Metalurgija, Vol. 49, 123-126.

[4] Roy, R. K. (2001). Design of experiments using the Taguchi approach: 16 steps to product and process improvement, John Wiley \& Sons, Inc.

[5] Mahto, D., Kumar, A. (2008). Optimization of process parameters in vertical CNC mill machines using Taguchi's design of experiments, ARISER, Vol. 4, No. 2, 61-75.

[6] Ghani, J. A., Choudhary, I. A., Hassan, H. H. (2004). Aplication of Taguchi method in optimization of end milling parameters, Journal of Materials Processing Technology, Vol. 145, 84-92.

[7] Sekulic, M., Hadzistevic, M., Jurkovic, Z., Kovac, P., Gostimirovic, M. (2011). Application of Taguchi method in optimization of face milling parameters, 34th International Conference on Production Engineering, Serbia, 57-60.

[8] Kopač, J., Krajnik, P. (2007). Robust design of flank milling parameters based on grey-Taguchi method, Journal of Materials Processing Technology, Vol. 191, No. 1/3, 400-403.

[9] Pušavec, F., Kramar, D., Krajnik, P., Kopac, J. (2010). Transitioning to sustainable production-part II: evaluation of sustainable machining technologies, Journal of Cleaner Production, Vol. 18, 174-184.

[10] Kramar, D., Kopac, J. (2009). High performance manufacturing aspect of hard-to-machine materials, Advances in Production Engineering \& Management, Vol. 4, 3-14.

[11] Kramar, D. (2009). High-pressure cooling assistance in machining of hard-to-machine materials, PhD Thesis, Faculty of Mechanical Engineering, Ljubljana. 